Abstracta Iranicacta Iranica

Revue bibliographique pour le domaine irano-aryen

Volume 32-33 | 2013

Comptes rendus des publications de 2009-2010

\title{
Stefan R. Hauser, David J. Tuckler. The Final Onslaught. The Sasanian Siege of Hatra
}

\section{Rémy Boucharlat}

\section{(2) OpenEdition}

1 Journals

Édition électronique

URL : http://journals.openedition.org/abstractairanica/40513

DOI : 10.4000/abstractairanica.40513

ISSN : 1961-960X

\section{Éditeur :}

CNRS (UMR 7528 Mondes iraniens et indiens), Éditions de l'IFRI

\section{Édition imprimée}

Date de publication : 1 décembre 2013

ISSN : 0240-8910

\section{Référence électronique}

Rémy Boucharlat, «Stefan R. Hauser, David J. Tuckler. The Final Onslaught. The Sasanian Siege of Hatra ", Abstracta Iranica [En ligne], Volume 32-33 | 2013, document 170, mis en ligne le 01 juillet 2016, consulté le 05 octobre 2020. URL : http://journals.openedition.org/abstractairanica/40513 ; DOI : https://doi.org/10.4000/abstractairanica.40513

Ce document a été généré automatiquement le 5 octobre 2020.

Tous droits réservés 


\title{
Stefan R. Hauser, David J. Tuckler. The Final Onslaught. The Sasanian Siege of Hatra
}

\author{
Rémy Boucharlat
}

\section{RÉFÉRENCE}

Stefan R. Hauser, David J. Tuckler. « The Final Onslaught. The Sasanian Siege of Hatra ». ZOrA, 2, 2009, p. 106-139.

1 Le siège de Hatra dans le nord de la Mésopotamie, à 90km au sud-ouest de Mossoul, fut un des plus importants de l'Antiquité. Pour prendre la ville en 240/241, il fallut à Ardešĩ I deux ans face à la triple enceinte et aux deux cents tours de remparts de la ville circulaire. L'exploration du site, classé au Patrimoine mondial, s'est limité aux premières lignes de défense. A l'aide des images satellites, images CORONA des années 60 comparées aux images récentes QuickBird, plus précises, les AA. étudient les défenses plus lointaines et l'hinterland steppique que l'on a longtemps considéré comme désertique. Ils révèlent plus précisément l'Eastern Enclosure' de 285 ha, à côté de la ville elle-même, qui aurait été le camp sassanide. Cette armée savait tenir un siège, en termes de poliorcétique, comme de logistique pour assurer le ravitaillement des troupes en milieu hostile. On connaît d'autres exemples fameux, comme le siège victorieux de Dura-Europos et de Nisibe. 


\section{AUTEURS}

RÉMY BOUCHARLAT

CNRS, Lyon 